\title{
Impact of Covid-19 Pandemic on Financial Performance in Sub-Sector Pharma- ceutical Companies Listed on the IDX
}

\author{
Agung Zulfikri* Tera Lesmana, Gustian Djuanda
}

Nusa Putra University, West Java, Indonesia

*Corresponding author:

E-mail:

agung.zulfikri_MN18@nusapu-

tra.ac.id

\begin{abstract}
This study aims to analyze the effect of companies' financial performance amid a pandemic in pharmaceutical companies listed on the IDX. This study uses the financial ratios of EPS and ROE as independent variables. The results show that EPS and ROE positively affect stock prices, which means that each increase in EPS and ROE will increase stock prices. To increase stock prices, companies should make efficient and increase ROE. This study's objects are three companies, namely sub-companies - the pharmaceutical sector on the IDX for the period 2018 to 2020. The results of this study, EPS, and ROE do not affect share prices simultaneously.
\end{abstract}

Keywords:EPS (Earning Per Share), ROE (Return On Equity), profitability ratio.

\section{Introduction}

Coronavirus disease 2019, or (COVID-19) is an infectious disease caused by a new strain called Coronavirus, which was first reported in China in December 2019. Wuhan Health Organization Duni, a World Health Organization (WHO), states that the Coronavirus is a virus that infects the respiratory system, the most common symptoms of exposure to this virus are fever, dry cough, and fatigue. However, some have been infected with Covid-19 but do not show any symptoms or are called people without symptoms (OTG). This Coronavirus is a zoonotic that can be transmitted between humans and animals. The spread of this virus is speedy, even to various countries around the world, including Indonesia.

The entry of Covid-19 in Indonesia has undoubtedly had a significant impact on economic growth. To break the chain of the spread of covid-19, the Indonesian government urges people not to move outside the home. The Indonesian government implements a policy of large-scale social distancing and social restrictions (PSBB). The Indonesian government policy during the Covid-19 pandemic hurt the Indonesian economy, where the impact of this policy was the cessation of economic activities in Indonesia.

The COVID-19 pandemic has also had a dire impact on investment, making people choose to be very careful in buying goods and even investing. This pandemic has also greatly affected market projections. Investors can tend not to invest due to changing market assumptions and unclear supply chains (Pepinsky \& Wihardja, 2011).

Indonesia has made restriction policies for travel to and from countries in the red zone of transmission during the COVID-19 pandemic to break the chain of transmission of COVID-19. This step follows policies that have already been implemented by several countries. The restriction policy for traveling to countries included in the red zone of COVID-19 transmission has been carried out by Indonesia and has also been implemented by Australia, China, Russia, Italy, Singapore, and other countries.

The Indonesian economy is experiencing a slowdown, which is the impact of the Covid-19 pandemic. Various economic support activities have become stagnant, some of which include the cessation of export and import activities, the closure of Indonesian flights, and many other sectors that have had

\section{How to cite:}

Zulkfikri, A., Lesmana, T., \& Djuanda, G. (2021). Impact of covid-19 pandemic on financial performance in sub-sector pharmaceutical companies listed on The IDX. $1^{\text {st }}$ ICEMAC 2020: International Conference on Economics, Management, and Accounting. NST Proceedings. pages 138-144. doi: 10.11594/ nstp.2021.1016 
to be stopped, which has resulted in a slowdown in the rate of investment in Indonesia and high levels of unemployment in Indonesia. The cessation of exports and imports also impacts the limited supply of medicines and medical equipment; this is because Indonesia has not been able to meet the needs of its medicines and medical devices.

The pharmaceutical industry is a determinant of the availability of drugs. The pharmaceutical industry plays a role in producing and distributing drugs to meet market and community needs. During the Covid-19 pandemic, pharmaceutical sub-sector companies needed to adapt to this due to delays in supply chains of raw materials for medicines and medical devices due to restrictions on activities amid the Covid-19 pandemic.

\section{Literature Review \\ Signal theory}

Ros developed signaling Theory (signal theory) in 1997. This Theory explains why companies provide financial reports as information to outsiders, such as the capital market, and how companies should provide signals to parties using financial reports.

Referring to (Hartono, 2013), signaling theory emphasizes the importance of the company's information on interested parties' investment decisions outside the company. Signal theory shows the existence of information asymmetry between the company and those who need information. For this reason, it is necessary to publish financial reports as information to interested parties.

\section{Financial performance}

Referring to (Sutrisno, 2009) financial performance is an achievement achieved by a company in a certain period and reflects the company's health level. Financial performance results from achievements that management has achieved in carrying out its function as manager of company assets for a certain period (Rudianto, 2013). Measurement of financial performance is necessary for financial managers or company stakeholders to make decisions that the company must take to be right on target. Measurement of financial performance aims to determine the level of liquidity, level of solvency, level of profitability, and stability level.

\section{Stock price}

The share price is the price set on the capital market at a certain period, and the share price can change at any time because the share price itself is influenced by the supply and demand that occurs in the capital market for these shares. The share price is formed through the supply and demand mechanism in the capital market. Other factors that can influence stock price movements are external constraints such as economic activity in general, taxes, and the stock market condition (Sartono, 2001).

\section{The scope of research}

The benefits of the profitability ratio is as follows:

a. Knowing the company's profit position in the previous year and also the current year

b. know the level of profit development.

c. Knowing the level of net profit after tax and own profit.

This research's scope is "The impact of a covid-19 pandemic on financial performance in sub-sector pharmaceutical companies listed on the I. The financial performance is seen from the financial ratios, namely ROE (Return on Equity) and EPS (Earning per share) Q in Q1 1,2, and 3 in the 2018 - 2020 period.

\section{Research design}

The research design is an associative study to determine the relationship between two or more variables in a causal relationship. According to Rochaety et al. (2007), a causal relationship is a causal relationship between the independent and dependent variables. 


\section{Data source}

This study uses secondary data, namely quantitative data sourced from the website (www.IDX.co.id). The data used in this study are financial statement data of 1, 2, and 3 of the pharmaceutical sub-sector companies, namely PT. Kimia Farma Tbk, PT Darya-Varia Laboratoria Tbk, and PT Kalbe Farma Tbk in 2018 - 2020.

\section{Population and Sample}

D nature of this study population used is the delivery of the pharmaceutical sub-sector company PT. Kimia Farma Tbk, PT Darya-Varia Laboratoria Tbk, and PT Kalbe Farma Tbk. The sub pharmaceutical sector's use is due to the sub-sector pharmaceutical is Integration Integration's significant role in supporting medicines and medical devices in the middle of the 19th COVID pandemic. The sampling technique used in this research uses the purposive sampling method, namely determining the sample with specific criteria. The sample criteria in this study are as follows:

a) Pharmaceutical Subsector

b) Issuing reports quarterly financial 1,2, and 3 respectively from 2018 - 2020.

c) The company has complete ratios such as ROE and EPS

\section{Operational definition and variable measurement}

D nature of this study population used is the delivery of the pharmaceutical sub-sector company PT. Kimia Farma Tbk, PT Darya-Varia Laboratoria Tbk, and PT Kalbe Farma Tbk. The sub pharmaceutical sector's use is due to the sub-sector pharmaceutical is Integration Integration's significant role in supporting medicines and medical

This study uses two types of variables, namely:

1. Dependent Variable

The dependent variable is the dependent variable, which is influenced by independent variables (Sugiyono, 2018). In this study, the dependent variable to be used is financial performance (Y), measured using ROE and EPS.

a. Return on Equity (ROE)

The ROE ratio is used to measure a company's strength in using its equity to generate profits for shareholders. If this ROE ratio shows a high yield, it shows positive results for the company. According to Hery (2015) Return on Equity (ROE) shows the level of capital contribution in creating net income. The formula used in measuring ROE is as follows:

$\mathrm{ROE}=\frac{\text { Equity }}{\text { Net Profit After Tax }} \times 100 \%$

b. Earnings per Share (EPS)

According to (Kasmir 2010), the earnings per share (EPS) or book value ratio is a ratio measuring the success rate of management in achieving shareholders' profits.

The formula for calculating earnings per share is as follows:

$$
\text { EPS }=\frac{\text { Net Profit }}{\text { The number of shares outstanding }}
$$

\section{Analysis technique}

The technique of analysis in this research, different test is used. The difference test is used to look for differences between two data samples or several data samples. This analysis technique was chosen to obtain a comparison of the company's financial performance before and after the COVID-19 pandemic. 


\section{Results and Discussion \\ Return on Equity (ROE)}

According to Mardiyanto (2009) ROE is a ratio used to measure a company's success in generating profits for shareholders. ROE is considered as a representation of shareholder wealth or company value. According to Riyadi (2006) Return on Equity (ROE) is a comparison between net income and the company's capital (core capital). This ratio shows the percentage level that can be generated. ROE is significant for shareholders and potential investors because a high ROE means that shareholders will receive high dividends, and an increase in ROE will cause an increase in shares.

Fred and (Weston, 1999) argue that "the ratio of net income after tax to equity is used to measure the rate of return on investment of shareholders."

According to Tambunan (2007) ROE is used to measure the return rate (rate of return) equity. Securities analysts and shareholders generally pay close attention to this ratio. The higher the ROE a company generates, the higher its share price.

According to Ika Lestari \& Sugiharto (2007), ROE is a ratio used to measure the net profit obtained from managing capital invested by the company owner. ROE is measured by the ratio between net income and total capital. The higher ROE figure indicates to shareholders that the return on investment is getting higher.

Table 1. ROE of PT. Kimi Farma

\begin{tabular}{cccc}
\hline PERIOD & 2018 & 2019 & 2020 \\
\hline QI & $21 \%$ & $26 \%$ & $12 \%$ \\
Q II & $19 \%$ & $18 \%$ & $17 \%$ \\
Q III & $18 \%$ & $17 \%$ & $12 \%$ \\
Q IV & $17 \%$ & $17 \%$ & $0 \%$ \\
\hline
\end{tabular}

Source: Data processed by the author

In the return On Equity (ROE) variable in Table 1, the results show that this affects stock prices, indicated by the value of the difference in the increase in each quarter in 2018-2020. Share prices experienced a sharp decline in the third quarter of 2019 to the third quarter of 2020, which was due to the impact of the Covid-19 pandemic. These results indicate that the return on investment that investors will receive is low so that investors are not interested in buying these shares, which causes the stock market price to fall. A company must increase ROE because the company must increase capital and increase the use of capital to increase profits so that ROE becomes high and will increase the company's stock price.

Table 2. ROE Darya-Varia Laboratoria Tbk

\begin{tabular}{cccc}
\hline PERIOD & 2018 & 2019 & 2020 \\
\hline QI & $5 \%$ & $2 \%$ & $-3 \%$ \\
Q II & $7 \%$ & $133 \%$ & $0 \%$ \\
Q III & $10 \%$ & $50 \%$ & $-1 \%$ \\
Q IV & $24 \%$ & $64 \%$ & $0 \%$ \\
\hline
\end{tabular}

Source: Data processed by the author

Table 2, the company Darya-Varia Laboratoria Tbk, is seen experiencing a stable Return Return every quarter of each year. 
Table 3. ROE Kalbe Farma Tbk

\begin{tabular}{cccc}
\hline PERIOD & 2018 & 2019 & 2020 \\
\hline QI & $17 \%$ & $15 \%$ & $18 \%$ \\
Q II & $18 \%$ & $17 \%$ & $17 \%$ \\
Q III & $17 \%$ & $16 \%$ & $16 \%$ \\
Q IV & $17 \%$ & $17 \%$ & $0 \%$ \\
\hline
\end{tabular}

Source: Data www.idx.co .

In table 3, PT Kablbe Farma's Return on Equity (ROE) experienced a decline in the third quarter and UV in 2018 and experienced an increase in 2019 in the first and second quarters but decreased in the third and fourth quarters, while in 2020 it experienced a decline in the third and fourth quarters I and Quarter III.

\section{Earnings per Share (EPS)}

EPS is considered the most basic information because it can describe the company's future earnings prospects and come (Tandelilin, 2001) If the EPS is produced following the expectations investor, then investors' interests to invest will increase. The increase in share prices is in line with the high demand for shares. Referring to Halim (2005) earnings per share (earnings per share) compares the net profit after tax obtained by the issuer with the number of shares outstanding. From the results of the research conducted, the following results were obtained:

Table 4. EPS PT. Kimi Farma

\begin{tabular}{cccc}
\hline PERIOD & 2018 & 2019 & 2020 \\
\hline QI & 12.57 & 12.69 & 55.87 \\
Q II & 25.94 & 26.84 & 29.6 \\
Q III & 38.49 & 48.6 & 43.25 \\
Q IV & 52.42 & 52.48 & \\
\hline
\end{tabular}

Source: Data processed by the author

From the results of the analysis above in table 4, the results of earnings per share in $2018(Q 1)$ are obtained, namely $6.7(Q 2)$, $21.97(Q 3) 40.56$, and $(Q 4) 74.88$, then at 2019 (Q 1) $3.71(Q 2) 8.6$ $(Q 3) 7.53(Q 4)-2.29$ and in 2020 the EPS value of PT. Kimia Farma, namely $(Q 1) 4.71(Q 2) 8.75$ and $(Q 3) \quad 6.7$.

Table 5. EPS Darya-Varia Laboratoria Tbk

\begin{tabular}{cccc}
\hline PERIOD & 2018 & 2019 & 2020 \\
\hline QI & 6.7 & 3.71 & 4.71 \\
Q II & 21.97 & 8.6 & 8.75 \\
Q III & 40.56 & 7.53 & 6.7 \\
Q IV & 74.88 & -2.29 & \\
\hline
\end{tabular}

Source: Data www.idx.co.

From the results of the analysis in table 5, the results obtained earnings per share in $2018(Q 1)$, which is equal to $56(Q 2) 97(Q 3) 146$ and $(Q 4) 180$ and then at $2019(Q 1) 75(Q 2) 102(Q 3) 159$ (Q4) 198 and in 2020 the EPS value of PT. Darya Varia laboratory Tbk, namely (Q 1) 50 (Q2) 124 and $(Q 3) 132$. 
Table 6. EPS Kalbe Farma Tbk

\begin{tabular}{cccc}
\hline PERIOD & 2018 & 2019 & 2020 \\
\hline QI & 56 & 75 & 50 \\
Q II & 97 & 102 & 124 \\
Q III & 146 & 159 & 132 \\
Q IV & 180 & 198 & 0 \\
\hline
\end{tabular}

Source: Data www.idx.co

From the results of the analysis above in Table 6, the result earnings per share in $2018(Q 1)$ which is equal to $12.57(Q 2) 25.94$ and $(Q 3) 38.49(Q 4) 52.42$ then at $2019(Q 1) 12.69(Q 2) 26.84(Q 3)$ $48.6(Q 4) 52.48$ and in 2020 the EPS value of PT. Kalalbe Farma Tbk Farma, namely $(Q$ 1) $55.87(Q 2) 29.6$ and $(Q 3) 43.25$.

\section{Conclusion}

EPS and ROE have a positive effect on stock prices, which means that each increase in EPS and ROE will increase the stock price; EPS and ROE are very much needed for an investor who is looking to invest in shares if you look at the ROE of the three companies above, it is still It is considered feasible to invest in a pharmaceutical sub-sector company because it can be seen that in every quarter the company experiences a stable condition even during the COVID-19 pandemic. In comparison, the three companies' EPS in a pandemic condition tends to move generally without a drastic decline. The decline in the value of EPS occurred at PT. Kimia Farma until -2.29, which is in Q4 2019.

\section{Research Limitations}

As consideration for further research to achieve maximum results, here are some limitations of this study:

a) This study only uses two financial ratios, namely EPS and ROE

b) In looking for financial performance, this study uses EPS and ROE as the dependent variable.

c) The study used three pharmaceutical sub-sector companies listed on the IDX through selectionaccording to this study's criteria.

d) The year period used is only three years, from 2018 to 2020 .

\section{Suggestions}

To achieve maximum results in future studies, the authors suggest:

a) Adding independent variables apart from the financial performance is another factor to strengthen the effect of financial performance on firm value.

b) Using other company subsectors.

c) Adding the period to the next observation year by more than three years

\section{Acknowledgment}

First, the author would like to thank many thanks to the Management Study Program at the University of Nusa Putra Sukabumi and all elements that have helped provide the opportunity to obtain this research data so that this research can run well and the author would like to thank ICEMAN 1st for the opportunity that has been taken give to authors to be able to participate and participate.

\section{References}

Halim, A. (2005). Investment analysis. Four Salemba.

Hartono, J. (2013). Business research methodology. Yogyakarta: Brief.

Hery. (2015). Financial statement analysis. Edition 1. In Yogyakarta: Center for Academic Publishing Services. 
Ika Lestari, M., \& Sugiharto, T. (2007). The performance of foreign exchange banks and non-foreign exchange banks and the factors that influence them.

Mardiyanto, H. (2009). The essence of financial management. Grand

Pepinsky, T. B., \& Wihardja, M. M. (2011). Decentralization and economic performance in Indonesia. Journal of East Asian Studies, 11 (3), 337-371.

Riyadi, S. (2006). Analysis of performance and health level of bank danamon after recapitalization and divestment. Muhammadiyah Surakarta University.

Rochaety, E., Tresnati, R., \& Latief, A. M. (2007). Business research methodology with the SPSS application. In Jakarta: Mitra Wacana Media.

Rudianto, E. (2013). Management accounting information for strategic decision making. Erlangga (p. 189).

Sartono, A. (2001). Financial management theory and applications. Yogyakarta: Before.

Sugiyono, PD (2018). Quantitative research methods, qualitative, and $R \& D$. (p. 39). Bandung: Alfabeta.

Sutrisno, H. (2009). Financial management theories, concepts and applications. Yogyakarta: Econosia

Tambunan, A, P. (2007). Assessing the fair price of shares. Alex Media Komputindo.

Tandelilin, E. (2001). Investment analysis and portfolio management. Yogyakarta: Bpfe.Rochaety 